\title{
Promoting the Agenda of Engineers: John Rawls and Justice in Engineering Ethics
}

\author{
David R. Haws \\ Boise State University
}

\begin{abstract}
:
When we lecture on engineering professional practice, we often begin with the public procedures of professional registration, and the public pronouncements of the Professional Engineer's Code of Ethics. Yet our discussions of engineering ethics typically focus on private rather than public autonomy. When can a kickback be seen as the cost of doing business? Should we launch a marginally safe but useful product? Should we sign a report that we know to be incomplete or deceptively worded? Theoretical ethics lends depth to our discussion and helps us to explain such dilemmas in terms of virtue, utility, or duty, but the questions themselves bear on engineering situations that disturb our private sense of morality and bear on private autonomy. We should also be concerned with the impact of engineering on public autonomy. What privileges can engineers legitimately claim? Who has the responsibility to oversee the engineer's professional conduct? To whom do engineers "owe" their public explanations?
\end{abstract}

The professionalization of engineering is an on-going process. Engineers are becoming "more" professional (a more specialized, essential core of knowledge; more restrictions on educational background; and less external oversight). Our students need to discuss the professional aspirations of engineers within the broader context of the social contract - the construct that holds our private and public autonomy together. What are the ethical implications of a dynamic social contract, and how might we justify the engineer's changing benefits and obligations? Theoretical ethics adds depth to our discussion here as well.

Much of engineering ethics must deal with the engineer's responsibility to society, and society's responsibility to engineers. We should approach engineering professionalization as an opportunity to discuss a number of views on the social contract (Socrates and the citizen's obligation of gratitude to the polis, Thomas Hobbes and the notion of absolute sovereignty, John Locke and rights of property, Jean-Jacques Rousseau and popular sovereignty, Immanuel Kant's "kingdom of ends," John Rawls and the concept of justice as fairness, and Jürgen Habermas and the procedures of discourse ethics). However, in this paper I will limit myself to the relevance of John Rawls and the problems of a "well-ordered" society. This will include a discussion of the two principles of justice, the original position, and the concept of primary goods - as may or may not justify the special privileges of professionalism claimed by engineers.

Introduction:

It seems apparent that our remote ancestors became socialized in nuclear and extended family groups, but why did they then choose to merge with other family groups to form larger social communities? Maybe they began to recognize that other contiguous family groups could provide 
a deeper gene pool, extended territorial span or perhaps just increased threat advantage. But once society extended beyond the family, the bond that held individuals together was something less. Society began to suffer plural conceptions of the good. Continued cooperation was contingent on benefits, and both benefits and burdens had to be seen as fair.

In our early societies, as in our earlier family groups, labor was divided. Yet the intimacy of the group ensured that while certain functions were performed by specific individuals, everyone had a basic understanding of the general process of everyone else's labor. Working together with labor specialization, the product of our industry was far greater than the sum of what we would have been able to achieve as individuals. The big problem was not measuring the benefits of society, but distributing them. There had to be an equitable relationship between contributions and benefits, or our remote ancestors would have simply joined some other society.

Perhaps it is erroneous to say that we "choose" to live together in a society today-most of us feel powerless to change the social order-but we "accept" society's benefits and burdens. How do we know that the benefits we receive and the burdens we endure are fair? Clearly, in our early societies, we could judge the labor and contributions of others and know whether we were being treated fairly. Even when there was no longer an alternate society to join, we could always state our case as eloquently as possible, and hope to persuade others. However, the practical force of arguments supporting our personal conception of the good often hinged on how well we understood the relative value of our own contribution.

As some personal contributions to the social order became more complex-less understandable to others - our ability to judge social contributions diminished. Nonetheless, in a free market the value of a contribution could always be determined by market forces. The problem here is perhaps two-fold. First, many contributions are irreducible to market values (how much is a loving parent worth?). Second, the market can be easily manipulated by those who have sufficient power. For example, when the aristocracy owned all the land (and had the muscle to enforce their ownership) your opportunity to grow crops on their land was worth what they said it was worth.

In the kind of complex society we have today, engineering has become less understandable to non-engineers. What is the social value of the Internet, or a stormwater retention dam, or an artificial heart? How much of that value should be attributed to the engineers who produced the designs? Engineering professionalization both enables more complex engineering products, and obscures the relative value of those products. In a free market economy, we might be willing to say that value is determined by whatever people are willing to pay. But when engineering is regulated by our collective professional aspirations (like land values were controlled by the nobility) we can hardly consider the market in engineering products to be unrestrained. If engineering professionalization obscures the value of engineering contributions, how does professionalization affect the social contract? This, I believe, is the crux of engineering ethicsnot interpersonal conduct between two morally equal individuals, but social conduct between the individuals of inherently unequal groups.

Far too often, in our courses on engineering ethics, we discuss engineering professionalism as an accomplished fact. Often we trot out the Canon of Ethics, as proof of our collective beneficence, 
and leave it at that. If we limit our discussions to the Canon, then we're guilty of wasting a wonderful opportunity to enrich our students' understanding of ethical thought as it relates to their incipient professionalism. In this paper, I want to discuss how engineering professionalization might be seen to affect the social contract from the perspective of John Rawls, including a discussion of the two principles of justice, the original position, and the concept of primary goods.

\section{Theoretical Background:}

John Rawls considers himself a Kantian scholar, and tends to downplay the originality of his own unique contributions. However, Rawls achieves a much clearer sense of hierarchy within the two principles of justice, than Kant was able to achieve with the notion of perfect and imperfect duties. Like most social-contract theorists, Rawls sees stability as the principal social function ${ }^{1}$. He feels that stability requires consensus, but that democracies foster plural, comprehensive worldviews. Rawls insists that his theory of justice as fairness is political rather than comprehensive ${ }^{2}$, but, like Kant's categorical imperative, it requires us to be reasonable as well as rational.

For Rawls, four conditions are critical for social stability. First, individuals have to be free and equal, regarding themselves as the source of legitimate claims on one another. Second, the conditions of justice have to be open to public scrutiny. Third, surplus goods created by the social union must be shared justly. And fourth, the social contract must carry an obligation for continued cooperation, to protect a shared investment in the social fabric. All of these conditions find their way into Rawls' construct of a just society.

Rawls' well-ordered society tries to find a stable balance in three traditional, often competing values: liberty, equality, and reward for services contributed to the common good. The conflict between liberty and equality is fairly obvious: strict equality would limit the liberty of nearly everyone to rise above the lowest common denominator. Required acts of service might also restrict one's liberty with an inequality of burdens, while reward for service implies inequalities in both burden and benefit.

Rawls believes that our concept of justice has to derive from a sense of moral equality, but that as individuals, we have unique gifts, opportunities, and agendas, and that strict equality is neither possible nor desirable. As a well-ordered society, we want people to exercise their valued talents because developed talents tend to improve the quality of life for everyone. But talents require personal effort to develop and exercise, and this effort can only be ensured if talents are rewarded. In the absence of reward, talents with social rather than personal benefits (like caring for the sick) would constitute an unequal burden. If there were no overweighing benefits attached to these talents, people would either hide them, or fail to develop them. Because we reward social contribution, there will be social inequalities of both benefits and burdens. These necessary inequalities will be acceptable, but only if they are seen as "fair."

In the face of inequalities, social stability derives from the obligation of fair play. Like Kant, Rawls believes that if the rules in a well-ordered society are justly developed, fair play demands that we support the social order even when the rules are not perfectly just. If the injustice in our 
society is too great for us to passively accept, then fair play requires civil disobedience rather than acts of rebellion. Such civil disobedience should be seen as an announcement to the rest of society that we believe a condition to be unjust - that we consider it a violation of the social contract, and that if the injustice isn't remedied, we will consider ourselves outside the constraints of society. Rawls believes that we have a prima facie duty of fair play, especially since we know that individuals in a just society are bound to experience inequalities. If we can arrive at a set of rules to ensure that inequalities are just, society will be stable enough to evolve rules and institutions that are more just.

Rawls believes that our sense of justice should be used to derive the basic structure of a wellordered society. He wants a set of guiding principles that are general, universal, publicly derived and avowed, and that impose a hierarchical order for conflicting claims. When these principles are agreed upon, he believes that they should be considered final, and therefore agreement on the principles needs to be unanimous. To meet these conditions, Rawls uses a hypothetical construct, which he calls the original position.

Rawls believes that society would derive just principles if its members were able to deliberate from a position of equality. He assumes that all the participants in this original position of equality are rational, and that they have the minimum capacity of a moral person. For Rawls, this minimum capacity involves a sense of justice and a personal conception of the good.

The problem for Rawls is that he wants his hypothetical group to come to a unanimous decision concerning the principles of justice. On the one hand, he realizes that people will never agree to a just system if they know too much about their own interests. On the other hand, any agreement would be meaningless if the individuals were operating from a position of total ignorance. Rawls wants to eliminate the bargaining advantages created by background institutions and an understanding of particulars: but how ignorant do individuals in the original position have to be? Kant's approach was to create a "thick" veil of ignorance (so that the participants know nothing) and then give them just enough knowledge to make a rational decision. Rawls decides to take the opposite approach: starting from an existing understanding, and eliminating any knowledge that might make it difficult to agree to a just set of principles.

From Rawls' original position then, individuals know that they will desire primary goods (they will all prefer a larger index of primary goods to a smaller one), and that they will have personal agendas to advance. They know that they will all be in a society together (they will be in the same place at the same time), and that some will have particular strengths and weaknesses (their standing in what Rawls calls the natural lottery of talents). They know that there will be inequalities: some will be born with more wealth, or from "better" families, and some will just be luckier than others. They also know that there will be few people at the "top." What they don't know is what their personal condition will be, or what personal conceptions of the good they will desire to advance.

From this position of ignorance concerning their own personal agendas and standing in the natural lottery, Rawls see two possible options: an open society based on a just distribution of primary goods, or a caste society where you take your chances on being born into any one of a number of castes. Under the caste system, the individual who fairs poorly in the natural lottery 
with regard to intelligence, talent, health and skill, might win the lottery by being born into the top caste. However, since there will be few positions in the more privileged castes, the odds of being born into the top caste would be fairly remote. Rawls concludes that an individual concerned with doing poorly in the natural lottery of talents, would give up any remote chance of being born to a high caste, if assured of just treatment in the event of loosing the natural lottery in an open society. In a sense, this follows from the logic of making choices to ensure the "best of the worst" possible outcomes. Here, the worst that can happen is to loose the natural lottery. The best of the worst outcomes would be to loose the natural lottery in an open society that would maximize access to primary goods (the worst of the worst would be to loose the natural lottery of talents and be born as an outcaste). Rawls derives the two principles of justice by imagining deliberations from the original position, concerning the conditions under which inequalities in primary goods would be considered just.

The two principles of justice are hierarchical in that the first principle takes precedence over the second principle, and part a) of the second principle takes precedence over part b).

1. Each person has an equal right to the most extensive scheme of equal basic liberties compatible with a similar scheme of liberties for all.

2. Social and economic inequalities are to satisfy two conditions. They must be

a. to the greatest benefit of the least advantaged members of society; and

b. attached to offices and positions open to all under conditions of fair equality of opportunity $^{3}$.

Basic liberties, referenced in the first principle, can be broken into four categories: political liberties (such as freedom of speech and freedom of assembly), liberties of conscience (for example, freedom of thought), liberties of person (freedom from physical assault) and liberties of property (freedom from arbitrary arrest and seizure). The primacy of the first principle indicates that liberties, which do not preclude like liberties for all, are not restricted for the sake of the second principle. Similarly, the first part of the second principle means that distribution for the greatest benefit to the least advantaged takes precedence over equal access to office and positions. According to this interpretation, it would be acceptable to restrict office, if equal access to offices decreased access to primary goods for the least advantages (in a later work ${ }^{4}$, Rawls reverses the order of the two parts of the second principle, ostensibly because he feels that the psychological damage of blatant unfairness outweighs the potential deprivation of primary goods). Rawls considers the basic liberties to be the first type of primary good, so the two principles of justice are really distributive in nature, and should be used to regulate fair access to a wide variety of primary goods.

Rawls' list of primary goods varied with time, but the central core seemed to involve basic liberties (diverse opportunities, freedom of movement, and choice of occupation), the power and prerogatives of offices and positions, income and wealth (understood broadly, to include things like health and educated intelligence), and the social basis of self-respect. Rawls feels that primary goods are generally necessary to support the individual's rational conception of the good (liberty is the opportunity to advance our personal conception of the good, but that opportunity is meaningless without the primary goods we use to pursue that conception). In addition Rawls 
sees fair access to primary goods as a stabilizing effect for two reasons. First, people who have access to a just portion of primary goods are less vulnerable and better able to protect themselves. Second, under a just distribution, people are less concerned with acquiring a greater index of primary goods and so existing goods are distributed more effectively.

Rawls and Engineering Professionalization:

As a general rule, engineers tend to have better access to primary goods than most of their fellow citizens. Rawls feels that, for social stability, better access to primary goods needs to be justified by merit-what he calls reciprocity. Engineers spend many years developing their talents, and this effort needs to be rewarded. Engineers design products that can be very valuable to the least advantaged (a dam that provides irrigation or flood control, transportation networks that allow migration away from areas of famine, facilities to provide clean drinking water). I think, for Rawls, the question of engineering professionalization would revolve around whether or not professionalization restricts fair and equal access to offices and positions in engineering in a way not required by part a) of the second principle.

The claim is that by restricting access to positions as a Professional Engineer, the profession is open to all on the basis of talent. The contention is that to loosen access, maybe getting a better demographic distribution of positions to women and minorities, would reduce the collective "talent" of the engineering pool and therefore reduce the benefits of engineering to the least advantaged. The notion that offices are open on the basis of talent is characteristic of the political system Rawls calls natural liberty. Rawls feels that we are moving away from a system of natural liberty and, ultimately, toward a political system of democratic equality, which requires that the least advantaged be "helped" to compete with the advantaged for offices and positions, such as those associated with the Professional Engineer. Certainly the engineering profession, which includes colleges of engineering, are making concerted efforts in this direction. As a consequence, I don't think that Rawls would object, from the principles of justice, to the self-regulation of the engineering profession, or the exclusion of access to the office of Professional Engineer on the basis of talents.

A more realistic problem for Rawls might be that part a) of the second principle (what he called the maximin criterion, because it tended to maximize the primary goods of those who have the minimum) might allow too large of a difference between the "haves-and-have-nots." This might arouse a socially destructive sense of envy, where individuals may opt for circumstances that make everyone worse off, if only the relative disparity in access to primary goods is reduced. Like Rousseau, Rawls feels that if inequalities are allowed to grow too large, they will destabilize society. To maintain stability in the face of inequalities, Rawls feels that we need to maintain a condition of publicity. Society needs to be visibly regulated by the two principles of justice. This involves the visible commitment of institutions, but also requires individuals to articulate their reasons for accepting the two principles of justice (reassuring everyone else that their commitments are stable).

To a certain extent, engineering professionalization is harmful to society's sense of public autonomy (here is a "class" of engineers doing something we don't understand, telling us we don't understand it enough to know how it might be regulated in the public interest, and demanding that we accept their self-regulation). However, the public's natural resentment of 
professionalization is not insurmountable. The Professional Engineer's Canon of Ethics is a good start, but it needs to be visibly and frequently reaffirmed within the more general community. Engineering education is good, but it doesn't reach everyone-and so there needs to be a continuing and meaningful dialog between engineers and non-engineers.

\section{Conclusions:}

So why should we, as engineers, pay particular attention to the theories of John Rawls? First, engineering is dependent on the health of the social contract. I can use engineering to design a beam for my house, but I could just as easily use my 15 years of experience as a carpenter to select the same beam. The point is that engineering isn't needed until "engineered works" expand beyond the envelope of vernacular experience. Engineering is only necessary when resources are pooled and projects become sufficiently large and complex. Without the willingness of a majority to exist within the social contract, there would be no engineering because there would be no need for engineered works.

Second, because societies are composed of individuals, social decisions will reflect the varying desires and beliefs (the personal agendas) of individuals. Yet for stability, societies need to be governed by established, slowly evolving rules rather than subjective desires and beliefs. As a consequence, most social contract theorists have tried to promote a "rule-generalized" approach to ethics, but with varied success. For example, Kant's "categorical imperative" is rulegeneralized, but lacks a coherent, effective hierarchy. As a parent, I experienced the categorical imperative's inadequacy when my son informed me that he was going to skip supper because he "promised" a friend that he would go outside and play. In such a situation, unless you can make a case that the duty to eat your supper (the duty to obey an implied promise to a parent) outweighs the duty to keep certain types of promises, the categorical imperative isn't much help. Rawls, by comparison, has been very effective in establishing an essential kind of hierarchy in his generalized rules.

Most engineering students (and professors) have little background in theoretical ethics, and so I hope that the information in this paper will help introduce Rawls' ethics theory into discussions of engineering professionalization. However, Rawls has to be recognized as just a beginning. I believe that Hobbes and Rousseau would also be concerned about engineering professionalization, to the extent that professionalization is seen as an attempt to evade sovereign oversight. Locke and Kant might be concerned that Professional Engineers exercise "paternal" power without fulfilling a responsibility to bring their fellows into active participation in decisions affecting engineered works. Rousseau as well as Rawls would want the privileges of engineers to be reciprocal (earned by merit), but neither would want the differences between the privileges of engineers and non-engineers to be too great. Kant as well as Rawls would be concerned that engineers become isolated to the point where they fail to see the value of private autonomy for non-engineers. Habermas would be concerned that engineering professionalization might monopolize knowledge. While there isn't room in this paper to touch on social contract theorist other than Rawls, these other theorists also embody concerns that need to be addressed by engineers.

It's important that our students be able to see the relevance of theoretical ethics, in terms of informing their own opinions, and communicating their personal conceptions of the good to 
others. Without an understanding of theoretical ethics, our students will be prone to ethical relativism, and will continue to have difficulty explaining their ethical resolutions to others. Rawls' theory of justice as fairness is a good place to start.

\section{References:}

1. Rawls, John (1999/1982). John Rawls: Collected Papers, Cambridge, Mass: Harvard University Press.

2. Rawls, John (1999/1971). A Theory of Justice, Cambridge, Mass: Harvard University Press.

3. Rawls, John (1999). Social Unity and Primary Goods, in John Rawls: Collected Papers, Cambridge, Mass: Harvard University Press, p. 362. Rawls' formulation of the these two principles varied significantly during his career.

4. Rawls, John (1996). Political Liberalism, New York: Columbia University Press.

\section{Biographical Information:}

My "professional" degrees are in Civil Engineering (an undergraduate degree from the University of Utah; and a master's and Ph.D. from Brigham Young University). I also have an undergraduate degree in English from the University of California at Berkeley, and a master's in Instructional and Performance Technology from Boise State University. I will complete a third master's in Technical Communication this coming winter at Boise State. 